Canadian

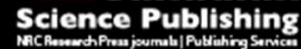

Canadian Journal of Microbiology Revue canadienne de de microbiologie

\title{
Degradation of Reactive Black 5 dye by a newly isolated bacterium Pseudomonas entomophila BS1
}

\begin{tabular}{|r|l|}
\hline Journal: & Canadian Journal of Microbiology \\
\hline Manuscript ID & cjm-2015-0552.R1 \\
\hline Manuscript Type: & Article \\
\hline Date Submitted by the Author: & $17-$ Nov-2015 \\
\hline Complete List of Authors: & $\begin{array}{l}\text { Khan, Sana; Aligarh MuslimUniversity, Department of Agricultural } \\
\text { Microbiology } \\
\text { Malik, Abdul; Aligarh Muslim University, Agricultural Microbiology }\end{array}$ \\
\hline Keyword: & $\begin{array}{l}\text { Azoreductase, Decolorization, Degradation, Reactive Black 5, Textile } \\
\text { industry }\end{array}$ \\
\hline
\end{tabular}


1 Degradation of Reactive Black 5 dye by a newly isolated bacterium Pseudomonas

2 entomophila BS1

3 Sana Khan, Abdul Malik*

4

5

6 Department of Agricultural Microbiology, Faculty of Agricultural Sciences, Aligarh Muslim

7 University, Aligarh, Uttar Pradesh, India-202002

8 *e-mail: ab_malik30@yahoo.com

9 Tel.: +91-571-2703516; Fax: +91-571-2703516

$10 *$ To whom correspondence should be addressed

11

12

13

14

15

16

17

18

19

20

21

22

23

24

25 


\section{Abstract}

27 The textile and dye industries are considered as one of the major sources of environmental 28 pollution. The present study was conducted to investigate the degradation of an azo dye 29 Reactive Black 5 (RB 5) using a bacterium isolated from soil samples collected around a 30 textile industry. The bacterial strain BS1 capable of degrading azo dye RB 5 was isolated and 31 identified as Pseudomonas entomophila based on 16S rDNA sequencing. Effects of different 32 parameters on the degradation of RB 5 was studied to find out the optimal conditions 33 required for maximum degradation which was $93 \%$ after $120 \mathrm{~h}$ of incubation. Static conditions with $\mathrm{pH}$ in the range of 5-9 and temperature of $37{ }^{\circ} \mathrm{C}$ were found to be optimum for degrading RB 5. Enzyme assays demonstrated that $P$. entomophila possessed azoreductase which played important role in degradation. The enzyme was dependent on FMN and NADH for its activity. Furthermore, possible degradation pathway of the dye was proposed through GC-MS analysis, which revealed that the metabolic products were naphthalene-1,2-diamine and 4-(methylsulfonyl) aniline. Thus the ability of this indigenous bacterial isolate for simultaneous decolorization and degradation of the azo dye signifies its potential application for treatment of industrial wastewaters containing azo dyes. 


\section{Introduction}

52 Azo dyes from textile and leather industry are common contaminants of soil and groundwater 53 in several countries. The situation is even worse in developing countries like India, where 54 about 1.5 million litres of dye related effluent, mostly untreated, is discharged by mills every 55 day; leading to chronic and acute toxicity to humans (Saratale et al. 2009). Presently, more 56 than 10,000 commercially available dyes are known. Azo dyes, used in textile industries, are 57 the largest group of dyes and constitutes about 60-70\% of all dye stuff production (Ong et al. 58 2010; Lang et al. 2013, Zhao et al. 2014). They possess one or more azo groups $\left(\mathrm{R}_{1}-\mathrm{N}=\mathrm{N}-\right.$ $59 \quad \mathrm{R}_{2}$ ) that are chromophores; and aromatic rings, the latter are mostly substituted by sulfonate 60 groups thereby making them highly soluble in water and hence difficult to be removed from 61 wastewater (Saratale et al. 2011). The complex structure and xenobiotic nature make the azo 62 dyes and their degradation products recalcitrant to biodegradation and, in many cases, they 63 have been reported to be both mutagenic and carcinogenic (Cartwright 1983; Chung and 64 Cerniglia 1992; Pinheiro et al. 2004). Therefore, effective removal of azo dyes from wastewater effluents before discharge into the environment has been a big challenge. In addition to the environmental concern, the textile industry consumes very large amounts of

67 potable water (800-1000 $\mathrm{m}^{3} \mathrm{ton}^{-1}$ of finished textile). In many countries where potable water 68 is scarcely available, this large water consumption has become intolerable and therefore, it is 69 recommended to recycle the wastewater in order to decrease the water requirements.

70 For the treatment of textile wastewater, several physico-chemical methods (like adsorption, 71 coagulation, flocculation, membrane filtration, ozonation, electrochemical, and radiolysis etc.) have been used. Although some of these processes have been effective, their application is limited due to the high cost, excess usage of chemicals, and excessive sludge generation with subsequent disposal problem (Saratale et al. 2011). Biological treatment methods are eco-friendly, have been proven to be efficient and more cost effective and hence are gaining 
76 importance in today's situation. Microorganisms such as actinomycetes, fungi, algae, yeast,

77 aerobic and anaerobic bacteria; and their enzymes have been successfully utilised to degrade 78 a wide variety of dyes (Kaushik and Malik 2009; Gupta et al. 2010a; 2010b; Srinivasan et al.

79 2014). The microbial enzymes are responsible for the degradation of different types of dyes.

80 Under anaerobic conditions, azo bonds of dyes are broken with relative ease and results in the

81 formation of corresponding aromatic amines, which are more toxic than the parent dye.

$82 R-N=N-R^{\prime}+4 e+4 H^{+} \ldots \mathrm{R}-N_{2}+\mathrm{R}^{\prime}-N_{2}$

83 Metabolism of these colorless aromatic amines varies in different strains of microorganisms

84 (Du et al. 2015). They may be further degraded aerobically or anaerobically by some strains

85 (Chang et al. 2004; Saratale et al. 2011) or remain resistant to degradation in other strains,

86 thereby causing environmental hazards (Murali et al. 2013).

87 Although decolorization of azo dyes by bacteria has been reported substantially (Chang and

88 Kuo 2000; Chen et al. 2003; Kalyani et al. 2009; Chang et al. 2011; Thakur et al. 2014),

89 information on possible degradation intermediates and enzymes involved in degradation

90 process is scanty. Moreover, in-depth characterization of native bacteria capable of efficient

91 dye decolorization and degradation would be ideal for utilization in wastewater treatment. In

92 the present study, an attempt has been made to isolate and characterize an efficient dye

93 degrading bacterium from wastewater contaminated soil. The nutritional requirements and

94 physico-chemical factors were optimized to enhance its degradation efficiency. Further, an

95 attempt was also made to understand the possible dye degradation pathway of RB 5 based on

96 GC-MS analysis of degradation products and involvement of reductive enzymes

97 (azoreductase).

$98 \quad$ Material and methods

99 Dyes and chemicals 
100 Reactive Black 5 is a high molecular weight (992 gmol $^{-1}$ ) diazo type reactive dye containing 101 vinyl sulfonate reactive groups, as represented by the chemical structure (Table 1). Reactive 102 Black 5 (Remazol Black B) dye used in this study was purchased from Sigma Aldrich (USA). 103 All other chemicals were of analytical grade, purchased from SRL and Hi-media 104 Laboratories, Mumbai, India.

105 Sample collection

106 Kanpur, located on the banks of the river Ganges between the parallels of $26^{\circ} 28^{\prime} \mathrm{N}$ and $10780^{\circ} 24^{\prime} \mathrm{E}$ is one of the important industrial centres of India, housing a large number of textile 108 as described by Aleem and Malik (2003), around the textile industries.

GC-MS analysis of textile wastewater

Textile wastewater was extracted with dichloromethane (DCM) as described in APHA (1998). Wastewater was filtered through whatman filter paper grade 1 (pore size $11 \mu \mathrm{m}$ ) and $0.45 \mu \mathrm{m}$ syringe filter (Millipore, USA). The wastewater was then extracted thrice with equal volume of dichloromethane (DCM). Aqueous and organic phases were separated using separating funnel. Organic phase containing the metabolites was collected from acidic and basic fractions. The extracted organic phase was evaporated at $40{ }^{\circ} \mathrm{C}$ under reduced pressure with the help of vacuum pump and made up to $5 \mathrm{~mL}$. These samples were filtered through $0.45 \mu \mathrm{m}$ membrane filter before they were used for GC-MS analysis.

123 Screening for dye degrading bacteria 
124 For the isolation of dye degrading bacteria enrichment technique was used. Nutrient broth 125 amended with RB 5 at $100 \mu \mathrm{gmL}^{-1}$ was inoculated with $10 \%$ of wastewater (v/v) and soil 126 samples (w/v) and cultured under microaerophilic (static) conditions at $37{ }^{\circ} \mathrm{C}$ for $48 \mathrm{~h} .100$ $127 \mu \mathrm{L}$ of the suspension was spread-plated on the nutrient agar plates containing RB 5 at 100 $128 \mu \mathrm{gmL}^{-1}$, following incubation the colonies with different morphology showing clear zone 129 were purified and taken for identification by sequencing of 16S rDNA.

$13016 \mathrm{~S}$ rDNA sequencing and phylogenetic analysis

131 Bacterial isolates were characterized by sequencing of $16 \mathrm{~S}$ rDNA. Total cell DNA was extracted from overnight grown cultures using Bacterial Genomic Miniprep Kit (Sigma, USA) as per manufacturer's instructions. PCR amplification of $16 \mathrm{~S}$ rRNA gene from the selected isolates was performed using the universal primers $27 \mathrm{f}$ and $1492 \mathrm{r}$ (Weisburg et al. 1991). PCR amplifications were carried out in a $25 \mu 1$ reaction volume containing $100 \mathrm{ng}$ of template DNA; at $0.5 \mu \mathrm{M}$ each primers; $10 \mathrm{mM}$ Tris-chloride $(\mathrm{pH} 8.3) ; 3.0 \mathrm{mM} \mathrm{MgCl}_{2}$; dNTP mix (Fermentas, USA) at $0.6 \mathrm{mM}$; and $1.25 \mathrm{U}$ of Taq DNA polymerase (Fermentas, USA). The reaction mixture was heated at $95{ }^{\circ} \mathrm{C}$ for 2 min followed by amplification in DNA thermal cycler (Biorad, USA) programmed for 30 cycles at $95{ }^{\circ} \mathrm{C}$ for $30 \mathrm{~s}, 57{ }^{\circ} \mathrm{C}$ for $60 \mathrm{~s}$ and $72{ }^{\circ} \mathrm{C}$ for $2 \mathrm{~min}$ and final extension at $72{ }^{\circ} \mathrm{C}$ for $10 \mathrm{~min}$. An aliquot of the each reaction mixture $(5 \mu \mathrm{l})$ was analyzed by agarose gel electrophoresis $(1.5 \%$ agarose $)$ to check for the expected amplicon of $1500 \mathrm{bp}$. The electrophoresed products were stained with ethidium bromide and visualized under UV light. The remaining amplified products were purified (QIAGEN Inc., Valencia, USA) and sequenced bi-directionally (Big Dye, Applied Bio Systems). The homology of the sequences obtained were determined by NCBI BLAST (Altschul et al. 1990). Sequences were aligned, verified and edited using Bioedit 7.2.0 (Hall 1999) and Molecular Evolutionary Genetics Analysis (MEGA v6.0) (Tamura et al. 2013) 
149 (Saitou and Nei 1987). The evolutionary distances were computed using the Maximum 150 Composite Likelihood method (Tamura et al. 2004). The analysis involved 47 nucleotide 151 sequences. Evolutionary analyses were conducted in MEGA v6.0 (Tamura et al. 2013).

152 Dye decolorization

153 Based on the 16S rDNA sequence analysis, one bacterium each from different genera were 154 tested for their dye decolorizing ability in LB broth (amended with $50 \mu \mathrm{gmL}^{-1}$ of the dye) and 155 incubated at $37{ }^{\circ} \mathrm{C}$ in a static condition. After every $24 \mathrm{~h}$, the culture was withdrawn upto 120 $156 \mathrm{~h}$ and centrifuged for $20 \mathrm{~min}$ at $8000 \times \mathrm{g}$. The supernatant was used for reading absorbance at $157597 \mathrm{~nm}\left(\lambda_{\max }\right.$ of RB 5). The percent decolorization was calculated spectrophotometrically, by 158 determining the initial absorbance (before decolorization) and final absorbance (after 159 decolorization).

$160 \%$ Decolorization $=\frac{\text { Initial absorbance }- \text { Final absorbance }}{\text { Initial absorbance }} \times 100$

161 Half-life $\left(\mathrm{t}_{1 / 2}\right)$ of the RB 5 degradation was also calculated using initial concentration $\left(\mathrm{N}_{0}\right)$ 162 and remaining concentration $\left(\mathrm{N}_{\mathrm{t}}\right)$ of RB 5 after $120 \mathrm{~h}(\mathrm{~T})$ of incubation as follows:

$$
\begin{gathered}
N_{t}=N_{0} \times 1 / 2{ }^{n} \\
T=t_{1 / 2} \times n
\end{gathered}
$$

163 Based on decolorization efficiency, one bacterial strain identified as Pseudomonas 164 entomophila BS1 exhibiting the highest RB 5 decolorizing ability was taken for further 165 studies.

166 Mode of decolorization (physical adsorption v/s biodegradation) and effects of different 167 parameters on decolorization process

168 In order to determine the possible way of decolorization, the heat killed and the living cells of 169 the bacterium were used for calculating the percent decolorization. For all of the 170 decolorization studies, each experiment was performed in triplicate. Effects of different 171 parameters on decolorization of RB 5 by growing cells of $P$. entomophila BS1 including dye 
172 concentration $\left(50,100,200,300,400\right.$ and $\left.500 \mu \mathrm{gmL}^{-1}\right)$, temperature $\left(25,30\right.$ and $\left.37{ }^{\circ} \mathrm{C}\right)$,

173 initial $\mathrm{pH}\left(4,5,6,7,8\right.$ and 9), salt concentration $\left(0,5,10,20,40,60,80\right.$, and $\left.100 \mathrm{gL}^{-1}\right)$ and

174 shaker speed $(50,100,150$ and $200 \mathrm{rpm})$ were investigated. Overnight bacterial culture was

175 inoculated in LB broth, amended with $50 \mu \mathrm{gmL}^{-1}$ of $\mathrm{RB} 5$ dye (except for when using

176 different dye concentrations). Inoculated medium was incubated at $37{ }^{\circ} \mathrm{C}$ (except for when at

177 different temperatures) under static condition (except for when at different rpm). The extent

178 of decolorization was calculated and recorded.

179 Enzyme assay

180 Azoreductase activity was assayed by the method of Nachiyar and Rajakumar (2005). In

181 order to assay the enzyme responsible for degradation of the dye in P. entomophila BS1,

182 bacterial cells were harvested $(8000 \times \mathrm{g}, 20 \mathrm{~min})$, washed by $10 \mathrm{mM}$ sodium phosphate buffer

183 (pH 7.1) and suspended in an equal volume of $50 \mathrm{mM}$ sodium phosphate buffer (pH 7.1).

184 Following the addition of DNase and cell beads, the pellet was used for the preparation of

185 cell-free extract using cell mill. Enzyme assay was started with a reaction mixture containing 186 potassium phosphate buffer $(25 \mathrm{mM}, \mathrm{pH} 7.1)$, FMN $(10 \mu \mathrm{M})$, Dithiothreitol $(5 \mathrm{mM}), \mathrm{NADH}$

$187(0.1 \mathrm{mM})$, substrate ( $\mathrm{RB} 5$ dye, $30 \mu \mathrm{M}), \mathrm{ddH}_{2} \mathrm{O}$ and enzyme (cell-free extract). All the

188 reaction mixture, except $\mathrm{NADH}$, was pre-incubated at room temperature for 4 min and the

189 reaction was started by adding $\mathrm{NADH}$, and the mixture was monitored

190 spectrophotometrically at $597 \mathrm{~nm}$. The slope of the initial linear decrease in absorption was

191 taken for calculating the azoreductase activity based on the molar absorption coefficient of

192 RB $5\left(\varepsilon=21.329 \mathrm{mmol}^{-1} \mathrm{~cm}^{-1}\right)$. One unit of enzyme activity was defined as the amount of 193 enzyme required to decolorize $1 \mathrm{nmol}$ of dye per min under the assay conditions. The assay 194 was also done with different controlled conditions in order to determine the factors on which 195 the enzyme activity was dependent. Protein concentration of the cell-free extract was 196 determined by Bradford assay. All the assays were conducted in triplicate. 
197 Analysis of the degradation products

198 For determining the possible changes in the absorption spectra of the dye during the 199 degradation of RB 5 by $P$. entomophila BS1, the culture supernatant from the decolorized 200 media was scanned from 350-750 nm using a UV-vis spectrophotometer against a baseline 201 defined by the absorbance of clarified samples from dye free media. For biodegradation 202 analysis, nutrient broth amended with $50 \mu \mathrm{gmL}^{-1}$ of the dye, was incubated first in static and 203 then in shaking conditions. After decolorization of the broth, metabolites were extracted 204 thrice with equal volume of dichloromethane and were identified using gas chromatography 205 along with mass spectrometry with a VARIAN GC-MS-4000 gas chromatograph, a VARIAN 206 CP-8410 auto sampler and an ION TRAP mass spectrometer. The system was controlled by a 2070 VARIAN STAR MS WORK STATION v6.9.1. The chromatographic column was a 208 ZEBRON ZB-1701 (30 m $0.25 \mathrm{~mm}$ i.d.; $0.15 \mathrm{~mm}$ film thickness). The carrier gas was helium 209 at a pressure of 8.7 psi. The sample injection was made in split mode using a BRUKER210 GLASS liner. The compounds were identified on the basis of mass spectra and using the 211 NIST library (National Institute of Standards and Technology).

\section{Results}

213 The results of the present study showed that the bacterium P. entomophila BS1 is endowed 214 with a high ability of metabolizing the textile dye RB 5 at temperature of $37^{\circ} \mathrm{C}$ and in the $\mathrm{pH}$ 215 range of 5-9. It was found that the decolorization was mainly due to the degradation of the 216 dye by the action of azoreductase enzyme. The metabolic intermediates of the degradation 217 were naphthalene-1,2-diamine and 4-(methylsulfonyl) aniline, as analysed by GC-MS.

218 GC-MS analysis of wastewater

219 The mass spectra of fragments for the major peaks in the gas chromatograms of textile 220 wastewater at the particular retention time were compared with the mass spectra of the NIST 
221 library. GC-MS analysis revealed the presence of different organic compounds, mainly esters,

222 amines, carboxylic acids and other aliphatic and aromatic hydrocarbons (Table 2).

223 Screening of dye degrading bacteria

224 Forty one bacteria (15 and 26 each from textile industry wastewater and contaminated soil)

225 with colonies surrounded by a nearly decolorized zone were successfully isolated and then

226 acclimatized to high concentration of RB 5.

227 16S rDNA sequencing and Phylogenetic analysis

228 To determine the phylogenetic relationship among the selected isolates, a 1500 bp amplicon 229 corresponding to $16 \mathrm{~S}$ rDNA was successfully amplified and sequenced in all the 41 isolates.

230 The partial sequences were aligned with the $16 \mathrm{~S}$ rDNA sequences of the corresponding 231 sequences in GenBank (Accession no. NR102865, NR111998, NR114154, NR113812, 232 NR044338, NR113615) and compared using Bioedit (Version 7.2.0). It was observed that the 233 obtained sequences showed 97-100\% identity with the reported sequences on BLAST 234 analysis. The partial $16 \mathrm{~S}$ rDNA sequences were submitted to GenBank. Of the 41 isolates 235 tested, 27 were found to be most similar to Pseudomonas sp, 8 with Enterobacter sp, 3 with 236 Arthrobacter sp. and the remaining 3 isolates showed maximum identity with Pantoea sp., 237 Leclercia sp., and Ochrobactrum sp. Among all the selected isolates, Pseudomonas sp. was 238 the most abundant (27) followed by Enterobacter sp (8), Arthrobacter (3), Pantoea sp. (1), 239 Leclercia sp. (1), and Ochrobactrum sp. (1). A tree representing the phylogenetic relationship 240 among the 16S rDNA was constructed using Neighbor-joining method (Fig. 1) by MEGA 241 (version 6.0).

242 The accession numbers of the partial 16S rDNA sequences (KP684060- KP684100) obtained 243 in this study are available at NCBI (http: //www.ncbi.nlm. nih.gov/BLAST).

244 Dye decolorization 
245 Out of the 41 bacterial isolates, screened by $16 \mathrm{~S}$ rDNA sequence analysis, one bacterium 246 each from different genera were tested for their dye decolorizing ability and they showed 247 different levels of percent decolorization ranging from $65-93 \%$ after $120 \mathrm{~h}$ of incubation (data 248 not shown). Based on decolorization efficiency, one bacterial isolate BS1 showed maximum 249 decolorization potential, the bacterium was identified as P. entomophila based on the BLAST 250 analysis of 16S rRNA gene sequence (Fig. S1). P. entomophila BS1 was found to exhibit 251 significant decolorization of $77 \%$ after $48 \mathrm{~h}$ of incubation, and maximum value (93\%) was 252 achieved after $120 \mathrm{~h}$ of incubation. Half-life $\left(\mathrm{t}_{1 / 2}\right)$ of the RB 5 degradation was found to be 25333.38 h. Other soil bacterial isolates like Ps. monteilii BS7, Ps. fulva BS30, Enterobacter cloacae BS10 and Enterobacter aerogenes BS24 showed 74\%, 89\%, 77\% and $81 \%$ of the dye decolorization after $120 \mathrm{~h}$ of incubation, respectively.

Mode of decolorization (Physical adsorption v/s biodegradation) and effects of different parameters on decolorization process

When heat-killed bacterial cells were added in the culture medium, only $4 \%$ decolorization was observed after $120 \mathrm{~h}$ of incubation. In contrast, $88 \%$ was achieved in the culture inoculated with live bacterial cells (Fig. 2a). P. entomophila BS1 showed higher decolorizing capability at the temperatures of $30{ }^{\circ} \mathrm{C}$ and $37{ }^{\circ} \mathrm{C}$ (88 and $93 \%$ respectively) after $120 \mathrm{~h}$ of incubation while at room temperature $\left(25^{\circ} \mathrm{C}\right)$ only $67 \%$ of decolorization was observed (Fig. 2b). The bacterial isolate has shown good decolorization at the $\mathrm{pH}$ range of 5-9 (about $94 \%$ decolorization) (Fig. 2c) and at $\mathrm{pH} 4$ very insignificant reduction was observed. The isolate 265 grew well up to the concentration of $500 \mu \mathrm{gmL}^{-1}$ of the dye and has shown significant amount 266 of decolorization ( $80 \%$ at $500 \mu \mathrm{gmL}^{-1}$ ) (Fig. 2d). It was also found that with increasing dye 267 concentration, there is a gradual decrease in percentage decolorization $\left(93 \%\right.$ at $50 \mu \mathrm{gmL}^{-1}$ and $26880 \%$ at $500 \mathrm{\mu gmL}^{-1}$ ). The decolorization process appeared to be $\mathrm{O}_{2}$-sensitive, since percent 269 decolorization decreased with increasing the speed of the shaker incubator (Fig. 2e). 
270 Decolorization of the dye was about $93 \%$ under static condition, and significantly decreased 271 in aerobic condition (19\% and $14 \%$ at 150 and $200 \mathrm{rpm}$, respectively). Furthermore, the 272 bacterium was found to tolerate significantly high concentration of salt and simultaneously 273 decolorizing the dye as well. At salt concentration of $20 \mathrm{gL}^{-1}$, decolorization was observable 274 (51\% after $120 \mathrm{~h}$ of incubation). Decolorization process started to decrease when salt 275 concentration exceeded $40 \mathrm{gL}^{-1}$ and only $12 \%$ decolorization occurred at $100 \mathrm{gL}^{-1}$ salt 276 concentration (Fig. 2f).

277 Enzyme assay

278 Enzyme activity in the cell-free extract was found to be $0.0012 \mathrm{Umg}^{-1}$. When in the reaction 279 mixture either FMN or NADH was not added, the activity was found to be zero, which 280 showed that the enzyme was dependent on FMN as prosthetic group and NADH as co-factor 281 for the activity. Moreover the enzyme was appeared to be constitutively expressed, since the 282 activity was also recorded when no dye was added in the bacterial growth medium for the 283 preparation of cell-free extract (Table 3).

284 Analysis of degradation products

285 In order to propose the possible mechanism of degradation of the dye, UV-vis spectroscopy 286 and GC-MS analysis were carried out. The main visible absorption peak of Reactive Black 5 287 dye is shown (Fig. 3). The UV-vis scanning spectra (350-750 nm) of supernatants at different 288 time intervals exhibited that the intensity at $597 \mathrm{~nm}\left(\lambda_{\max }\right.$ of RB 5) obviously decreased and 289 reached virtually zero after $48 \mathrm{~h}$ of incubation which suggested that during the reaction, the 290 azo bond was cleaved, most likely mediated by azoreductase enzyme, with the primary 291 chromophore being destroyed.

292 Gas chromatogram of the degraded dye, extracted from decolorized medium (using 293 dichloromethane) showed seven different peaks (Fig. 4) which corresponded to different 294 product molecules. These product molecules then entered into mass spectrometer, which 
295

296

297

298

299

300

301

302

303

304

305

306

307

308

309

310

311

312

313

314

315

316

317

318

319

made each product molecule charged. These charged molecules were accelerated and broken into smaller charged fragments which were displayed as spectral plots (Fig. S2). From the molecular mass and the mass of the fragments, two intermediatory products were identified as naphthalene-1,2-diamine (retention time 17.260, $\mathrm{m} / \mathrm{z} \quad 158.20$ ) and 4(methylsulfonyl)aniline (retention time $22.785, \mathrm{~m} / \mathrm{z} 171.21$ ) respectively.

\section{Discussion}

Textile processing industries use a variety of chemicals, therefore, the effluent compositions vary greatly depending on the different processes, used fabrics and machinery (Bisschops and Spanjers 2003). The textile effluent is characterized by high alkalinity, suspended solids, biochemical oxygen demand, chemical oxygen demand, heat, color, acidity and trace metals such as $\mathrm{Cr}$, $\mathrm{As}, \mathrm{Cu}$ and $\mathrm{Zn}$, with dye concentrations generally below $1 \mathrm{gL}^{-1}$ (Kaushik and Malik 2009).

The removal of color from textile and dyes manufacturing industrial wastewaters has become a real challenge in recent years, since the persistent release of toxic pollutants from these industries have contaminated the surrounding soil and water bodies (Moosvi et al. 2005). In order to overcome this problem, different bacterial strains were isolated from the textile effluents and contaminated soils and screened for their ability to decolorize the textile azo dye. The isolation and screening of azo dye degrading microorganisms from sludge samples collected from the dye wastewater treatment sites have been reported previously (Chen et al. 2003; Senan and Abraham 2004; Khadijah et al. 2009), that indicated the natural adaptation of these microorganisms to survive in the presence of the toxic dyes (Khadijah et al. 2009). As per 16S rDNA sequence analysis, the sequences obtained showed $97-100 \%$ identity with the reported sequences on BLAST analysis. They were found to belong to six different genera indicating broad distribution of dye degrading enzymes across bacterial species/genera. The phylogenetic tree revealed that the identical sequences grouped together. Phylogenetic analysis of P. entomophila BS1 
320 revealed that it grouped with other reported sequences of $P$. entomophila and other related $321 \quad$ Pseudomonas sp. (Fig.1; Fig. S1).

322 The decolorization efficiency of $P$. entomophila BS1 is comparable to those reported by 323 Wang et al. (2009) and (2013), where in Enteobacter sp. EC3 and Bacillus sp. YZU1 showed $32492.6 \%$ (after $108 \mathrm{~h}$ of incubation) and 95\% decolorization (after $120 \mathrm{~h}$ of incubation), 325 respectively. Similarly, Garg et al. (2012) have also reported that Pseudomonas putida SKG3261 removed more than $90 \%$ of orange II dye within $96 \mathrm{~h}$ of incubation. Under anoxic 327 conditions, many bacterial strains like P. mirabilis, P. luteola, Pseudomonas sp. and K. rosea, 328 showing significant reduction of dyes, have also been reported (Chen et al. 1999; Chang et al. 329 2001). Since only $4 \%$ of decolorization occurred through adsorption, therefore, it can be 330 suggested that process is mainly due to degradation of the dye (Fig. 2a). 331 Heteropolysaccharide and lipid components of the cell wall contribute to the biosorption 332 capacity of a microorganism that in turn leads to strong force of attraction between the azo 333 dye and the cell wall (Solís et al. 2012). Adsorption of the dye has been mainly reported in 334 fungal isolates due to their large surface area and only in few bacteria where extra 335 polysaccharide production was found (Binupriya et al. 2010). The optimal temperature for the 336 decolorization of the dye was found to be $37{ }^{\circ} \mathrm{C}$ (Fig. 2b). Temperature is an important 337 parameter, as bacteria require optimal temperature for growth and enzyme production. At 338 optimal temperature, there is an optimal microbial growth and greater production of enzymes. 339 Dye decolorization process is inhibited at other temperatures (very high or low) due to the 340 loss of cell viability or deactivation of enzymes involved in the degradation (Cetin and 341 Donmez 2006). It has been previously reported that $37{ }^{\circ} \mathrm{C}$ is an optimal temperature for dye 342 decolorization in many bacterial isolates (Kolekar et al. 2008) and in bacterial consortia 343 (Saratale et al. 2010). $\mathrm{pH}$ plays an important role in microbial growth and azo dye 344 degradation and optimal $\mathrm{pH}$ for color removal have been found to be 6-10 (Chen et al. 2003; 
345 Kilic et al. 2007). $\mathrm{pH}$ of the textile effluent generally varies between 8-9. P. entomophila BS1 346 exhibited decolorizing ability at the $\mathrm{pH}$ range of 5-9 (about $~ 94 \%$ decolorization), that makes 347 it a promising strain for the effective bio-treatment of dye wastewater. Kalyani et al. (2008) 348 found that bacterial isolates like Bacillus subtilis, Brevibacillus laterosporus, Enterbacter sp, 349 E. coli and Pseudomonas luteola have decolorized different dyes at a wide $\mathrm{pH}$ range, 350 generally in the alkaline region. Percentage decolorization was found to be decreased with 351 increasing dye concentrations. This can be due to the toxicity of the dyes to bacteria that inhibit the metabolic activities at higher dye concentrations. Similar results have also been reported by Gopinath et al. (2009) that in Bacillus sp. dye decolorization deceases with increasing initial dye concentration. Since our isolate grew well up to the concentration of utilised for the treatment of colored wastewater. The process of decolorization was oxygen sensitive, as maximum decolorization occurred when the bacterium was incubated statically (Fig. 2e). Since in the presence of oxygen, instead of azo groups in the dyes, oxygen is preferred as an electron acceptor (Pearce et al. 2003). Similarly, this has been reported previously that biodegradation of dyes was inhibited in aerobic condition (Moosvi et al. 2005). The bacterium was found to grow and decolorize the dye at significantly high salt concentration $\left(20 \mathrm{gL}^{-1}\right)$. As salt concentration was further increased, both the bacterial growth and consequently decolorization decreased drastically, because high salt concentration affects osmotic pressure in the bacterial isolate that may even cause cell death (Kolekar et al. 2008; Wang et al. 2013).

Enzymes that cause reduction of azo groups are termed as azoreductases. Azoreductase is the key enzyme expressed in the dye degrading bacteria and can catalyse the reductive cleavage of azo bonds. Azoreductase enzymes have been reported in many organisms (Blumel and Stolz 2003; Chen et al. 2005). These enzymes are having broad specificity, may be tolerant 
370 or sensitive to oxygen, and may be FMN-dependent or independent. In the present study, the

371 bacterial azoreductase was found to be dependent on FMN and NADH for its activity and 372 was constitutively expressed (Table 3). In contrast, azoreductases isolated from several 373 bacteria have been shown to be inducible flavoproteins and able to use both NADH and 374 NADPH as electron donors (Russ et al. 2000). The initial step in azo dye degradation 375 involved reductive cleavage of azo bond with the help of azoreductase, leading to generation 376 of secondary aromatic amines. These amines were further converted into lower molecular 377 weight compounds via the action of other enzymes.

378 To detect the possible occurrence of biodegradation, control and treated dye samples were 379 analysed by UV-vis spectrophotometer and change in the peaks were recorded. The result 380 showed that the biodegradation played a more important role, as the major peak decreased 381 and reached virtually zero after $48 \mathrm{~h}$. Thus it can be concluded that azo bonds were cleaved 382 by azoreductase enzyme during the process leading to damage in the primary chromophore, 383 as also demonstrated by Oturkar et al. (2011) and Qu et al. (2012). Possible pathway for RB 5 384 dye degradation was proposed by GC-MS analysis. For the biological decolorization of azo 385 dyes, azo groups were first cleaved reductively by the bacterial azoreductase enzyme. The 386 corresponding amines thus produced might be further attacked by other enzymes.

\section{Conclusion}

388 The removal of dyes from aqueous effluent has received considerable attention within 389 environmental research. In this study, an effective RB 5 decolorizing bacterial strain, $P$. 390 entomophila BS1 was isolated. Decolorization is mainly due to degradation of RB 5 by 391 azoreductase enzyme, not simply a physical surface adsorption. For degradation, $P$. 392 entomophila simply needs a mild condition, which showed remarkable tolerance to high 393 concentrations of RB 5 (up to $500 \mathrm{mgL}^{-1}$ ). The ability of the strain to tolerate and degrade azo 
394 dye at a high concentration gives it an advantage for treatment of textile industry 395 wastewaters.

\section{Acknowledgements}

397 SK is thankful to the University Grants Commission (UGC), New Delhi, India for financial 398 assistance under Maulana Azad National Fellowship (MANF) scheme, and DAAD short term fellowship (Germany) to perform a part of work at Albert Ludwigs University of Freiburg, Germany. Sophisticated Analytical Instrument Facility, Indian Institute of Technology, Bombay is also acknowledged for the GC-MS analysis of the samples.

\section{References}

Aleem, A., and Malik, A. 2003. Genotoxic hazards of long-term application of wastewater on agricultural soil. Mutat. Res. 538: 145-154.

Altschul, S.F., Gish, W., and Miller, W. 1990. Basic local alignment search tool. J. Mol. Biol. 215: 403-410.

American Public Health Association. APHA. 1998. Standard methods for examination of water and wastewater. APHA, Washington, DC.

Binupriya, R., Sathishkumar, M., Ku, C.S., and Yun, S. 2010. Sequestration of Reactive Blue 4 by free and immobilized Bacillus subtilis cells and its extracellular polysaccharides. Colloids Surf., B 76: 179-185.

Bisschops, I., and Spanjers, H. 2003. Literature review on textile wastewater characterization. Environ. Technol. 24: 1399-1411.

Blumel, S., and Stolz, A. 2003. Cloning and characterisation of the gene coding for the aerobic azoreductase from Pigmentiphage kullae K24. Appl. Microbiol. Biotechnol. 62(2-3): 186-190.

Cartwright, R.A. 1983. Historical and modern epidemiological studies on populations exposed to N-substituted aryl compounds. Environ. Health Perspect. 49: 13-19. 
419 Cetin, D., and Donmez, G. 2006. Decolorization of reactive dyes by mixed cultures isolated 420 from textile effluent under anaerobic conditions. Enzyme Microb. Technol. 38: 926421930.

422 Chang, J.S., and Kuo T.S. 2000. Kinetics of bacterial decolorization of azo dye with $423 \quad$ Escherichia coli NO3. Bioresour. Technol. 75: 107-111.

424 Chang, J.S., Chou, C., and Chen, S.Y. 2011. Decolorization of azo dyes with immobilized $425 \quad$ Pseudomonas luteola. Process Biochem. 36: 757-763.

426 Chang, J.S., Chou, C., Lin, Y., Ho, J., and Hu, T.L. 2001. Kinetic characteristics of bacterial azo dye decolorization by Pseudomonas luteola. Water Res. 35: 2041-2850. 
Garg, S.K., Tripathi, M., Singh, S.K., and Tiwari, J.K. 2012. Biodecolorization of textile dye effluent by Pseudomonas putida SKG-1 (MTCC 10510) under the conditions optimized for monoazo dye orange II color removal in simulated minimal salt medium. Int. Biodeterior. Biodegrad. 74: 24-35.

Gopinath, K.P., Murugesan, S., Abrahamb, J., and Muthukumar, K. 2009. Bacillus sp. mutant for improved biodegradation of Congo red: random mutagenesis approach. Bioresour. Technol. 100: 6295-6300.

Gupta, V.K., and Rastogi, A. 2010b. Biosorption of nickel onto treated alga (Oedogoniumhatei): Application of isotherm and kinetic models. J. Colloid Interface Sci. 342: 533-539.

Gupta, V.K., Rastogi, A., and Nayak, A. 2010a. Adsorption studies on the removal of hexavalent chromium from aqueous solution using a low cost fertilizer industry waste material. J. Colloid Interface Sci. 342: 135-141.

Hall, T.A. 1999. BioEdit: a user-friendly biological sequence alignment editor and analysis program for Windows 95/98/NT. Nucleic Acids Symp. Ser. 41: 95-98.

Kalyani, D.C., Patil, P.S., Jadhav, J.P., and Govindwar, S.P. 2008. Biodegradation of reactive textile dye Red BLI by an isolated bacterium Pseudomonas sp. SUK1. Bioresour. Technol. 99: 4635-4641.

Kalyani, D.C., Telke, A.A., Dhanve, R.S., and Jadhav, J.P. 2009. Eco-friendly biodegradation and detoxification of reactive red 2 textile dye by newly isolated Pseudomonas sp. SUK1. J. Hazard. Mater. 163: 735-742.

Kaushik, P., and Malik, A. 2009. Fungal dye decolourisation: recent advances and future potential. Environ. Int. 35: 127-141. 
466 Khadijah, O., Lee, K.K., and Abdullah, M.F. 2009. Isolation, screening and development of

467

468

469

470

471

472

473

474

475

476

477

478

479

480

481

482

483

484

485

486

487

488 local bacterial consortia with azo dyes decolourising capability. Malays. J Microbiol. 5(1): 25- 32.

Kilic, N.K., Nielsen, J.L., Yuce, M., and Donmez, G. 2007. Characterization of a simple bacterial consortium for effective treatment of wastewaters with reactive dyes and $\mathrm{Cr}$ (VI). Chemosphere. 67: 826-831.

Kolekar, Y.M., Powar, S.P., Gawai, K.R., Lokhande, P.D., Shouche, Y.S., and Kodam, K.M. 2008. Decolorization and degradation of Disperse Blue 79 and Acid Orange 10, by Bacillus fusiformis KMK5 isolated from the textile dye contaminated soil. Bioresour. Technol. 99: 8999-9003.

Lang, W., Sirisansaneeyakul, S., Ngiwsara, L., Mendes, S., Martins, L.O., Okuyama, M., and Kimura, A. 2013. Characterization of a new oxygen-insensitive azoreductase from Brevibacillus laterosporus TISTR1911: Toward dye decolorization using a packed- bed metal affinity reactor. Bioresour. Technol. 150: 298-306.

Moosvi, S., Keharia, H., and Madamwar, D. 2005. Decolourization of textile dye Reactive Violet 5 by a newly isolated bacterial consortium RVM 11.1. World J. Microbiol. Biotechnol. 21: 667-672.

Murali, V., Ong, S.A., Ho, L.N., and Wong, Y.S. 2013. Evaluation of integrated anaerobicaerobic biofilm reactor for degradation of azo dye methyl orange. Bioresour. Technol. 143: $104-111$.

Nachiyar, C.V., and Rajakumar, G.S. 2005. Purification and characterization of an oxygen insensitive azoreductase from Pseudomonas aeruginosa. Enzyme Microb. Technol. 36: 503-509. 
Ong, S., Uchiyama, K., Inadama, D., Ishida, Y., and Yamagiwa, K. 2010. Treatment of azo dye Acid Orange 7 containing wastewater using up-flow constructed wetland with and without supplementary aeration. Bioresour. Technol. 101: 9049-9057.

Oturkar, C.C., Nemade, H.N., Mulik, P.M., Patole, M.S., and Hawaldar, R.R. 2011. Mechanistic investigation of decolorization and degradation of Reactive Red 120 by Bacillus lentus BI377. Bioresour. Technol. 102: 758-764.

Pearce, C.I., Lloyd, J.R., and Guthrie, J.T. 2003. The removal of color from textile wastewater using whole bacterial cells: a review. Dyes Pigm. 58: 179-196.

Pinheiro, H.M., Touraud, E., and Thomas, O. 2004. Aromatic amines from azo dye reduction: status review with emphasis on direct UV-spectrophotometric detection in textile industry wastewaters. Dyes Pigm. 61: 121-139.

Qu, Y., Cao, X., Ma, Q., Shi, S., Tan, L., Li, X., et al. 2012. Aerobic decolorization and degradation of Acid Red B by a newly isolated Pichia sp. TCL. J. Hazard. Mater. 223224: $31-38$.

Russ, R., Rau, J., and Stolz, A. 2000. The function of cytoplasmic flavin reductases in the reduction of azo dyes by bacteria. Appl. Environ. Microbiol. 66: 1429-34.

Saitou, N., and Nei, M. 1987. The neighbor-joining method: A new method for reconstructing trees. Mol. Biol. Evol. 4: 406-425.

Saratale, R.G., Saratale, G.D., Chang, J.S., and Govindwar, S.P. 2011. Bacterial decolorization and degradation of azo dyes: a review. J. Taiwan Inst. Chem. E. 42:

$138-157$.

Saratale, R.G., Saratale, G.D., Changand, J.S., and Govindwar, S.P. 2010. Decolorization and degradation of reactive dyes and dye wastewater by a developed bacterial consortium. Biodegradation. 21: 999-1015. 
513 Saratale, R.G., Saratale, G.D., Kalyani, D.C., Chang, J.S., and Govindwar, S.P. 2009.

514 Enhanced decolorization and biodegradation of textile azo dye Scarlet R by using

515 developed microbial consortium-GR. Bioresour. Technol. 100(9): 2493-2500.

516 Senan, R.C., and Abraham, E.T. 2004. Bioremediation of textile azo dyes by aerobic 517 bacterial consortium. Biodegradation. 15: 275-280.

518 Solís, M., Solís, A., Pérez, H. I., Manjarrez, N., and Flores M. 2012. Microbial decolouration 519 of azo dyes: A review. Process Biochem. 47: 1723-1748.

520 Srinivasan, G.P., Sikkanthar, A., Elamaran, A., Delma1, C.R., Subramaniyan, K., and 521 Somasundaram, S.T. 2014. Biodegradation of carcinogenic textile azo dyes 522 using bacterial isolates of mangrove sediment. J. Coast. Life Med. 2(2): 154-162.

523 Tamura, K., Nei, M., and Kumar, S. 2004. Prospects for inferring very large phylogenies by 524 using the neighbor-joining method. Proc. Natl. Acad. Sci. U. S. A. 101: 11030-11035. 525 Tamura, K., Stecher, G., Peterson, D., Filipski, A., and Kumar, S. 2013. MEGA6: Molecular 526 Evolutionary Genetics Analysis version 6.0. Mol. Biol. Evol. 30: 2725-2729.

527 Thakur, J.K., Paul, S., Dureja, P., Annapurna, K., Padaria, J.C., and Gopal, M. 2014. 528 Degradation of Sulphonated Azo Dye Red HE7B by Bacillus sp. and Elucidation of 529 Degradative Pathways. Curr. Microbiol. 69(2): 183-191.

530 Wang, H., Zheng, X.W., Su, J.Q., Tian, Y., Xiong, X.J., and Zheng, T.L. 2009. Biological 531 decolorization of the reactive dyes Reactive Black 5 by a novel isolated bacterial strain 532 Enterobacter sp. EC3. J. Hazard. Mater. 171: 654-659.

533 Wang, Z.W., Liang, J.S., and Liang, Y. 2013. Decolorization of Reactive Black 5 by a newly $534 \quad$ isolated bacterium Bacillus sp. YZU1. Int. Biodeterior. Biodegrad. 76: 41-48.

535 Weisburg, W.G., Barns, S.M., Pelletier, D.A., and Lane, D.J. 1991. 16S ribosomal DNA 536 amplification for phylogenetic study. J. Bacteriol. 173: 697-703. 
537 Zhao, H., Zhang, G.M., and Zhang, Q.L. 2014. $\mathrm{MnO}_{2} / \mathrm{CeO}_{2}$ for catalytic ultrasonic 538 degradation of methyl orange. Ultrason. Sonochem. 21: 991-996. 
Legends to Figures

Fig. 1. 16S rDNA sequence based phylogenetic tree of bacterial strains used in this study and related sequences obtained through BLAST analysis

Fig. 2. Decolorization of Reactive Black 5 dye by Pseudomonas entomophila BS1 (a) using live and dead cells (heat-killed) (b) temperatures (c) $\mathrm{pH}$ (d) initial dye concentrations (e) Different rpm, and (f) salt concentrations

Fig. 3. UV-vis spectra of Reactive Black 5 dye degradation by Pseudomonas entomophila BS1 at different time intervals

Fig. 4. Gas chromatogram of degraded products of Reactive Black 5 dye 


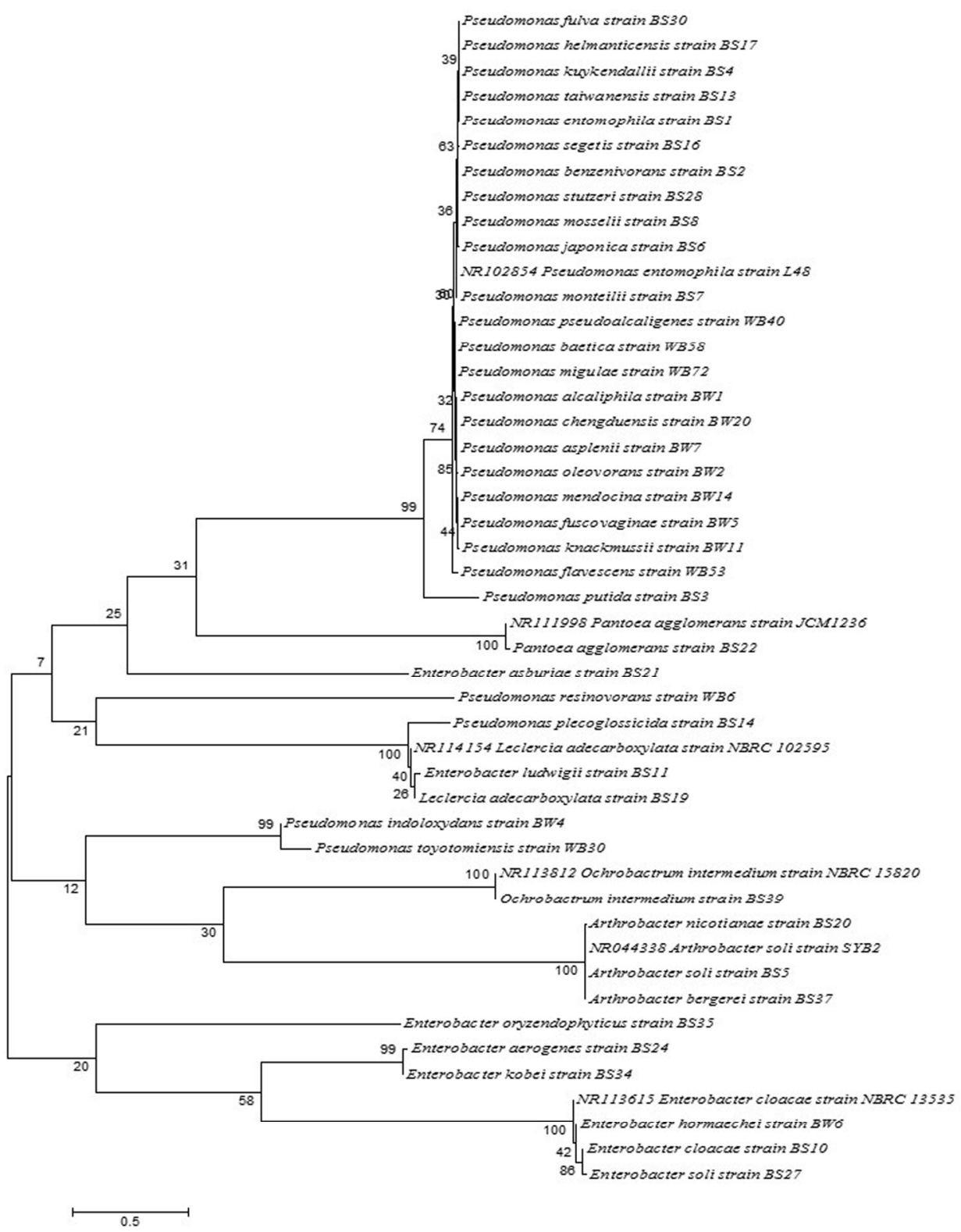

$136 \times 173 \mathrm{~mm}(300 \times 300 \mathrm{DPI})$ 

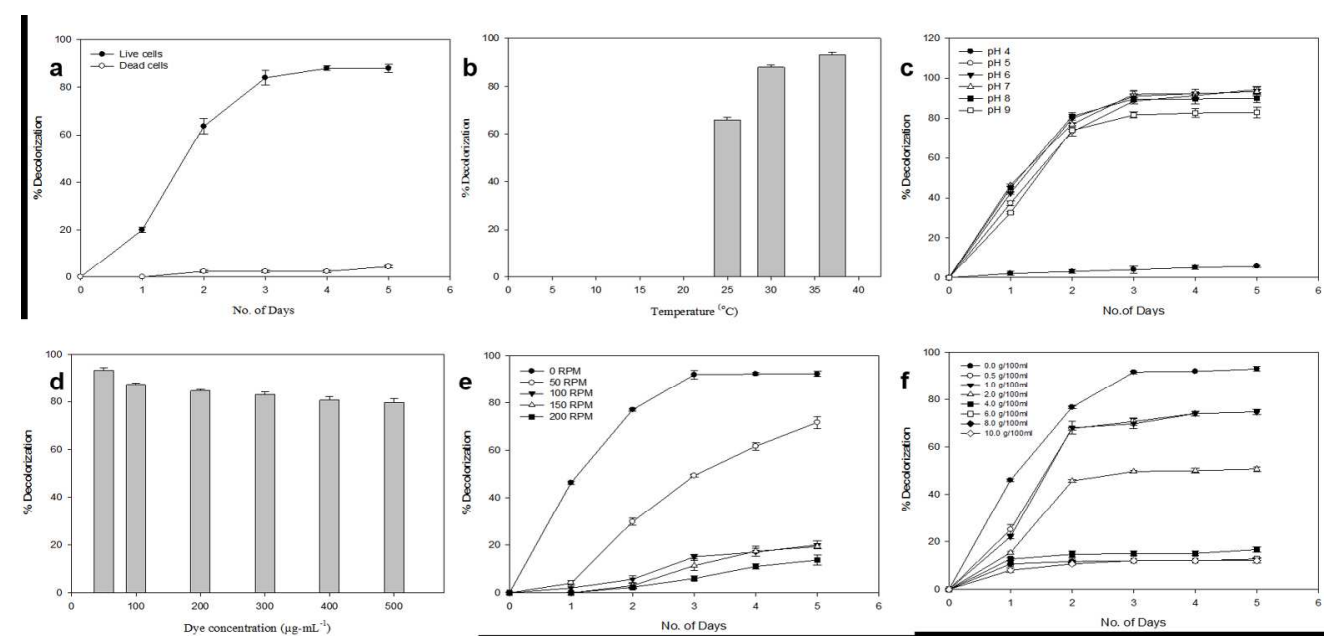

$164 \times 78 \mathrm{~mm}(300 \times 300 \mathrm{DPI})$ 


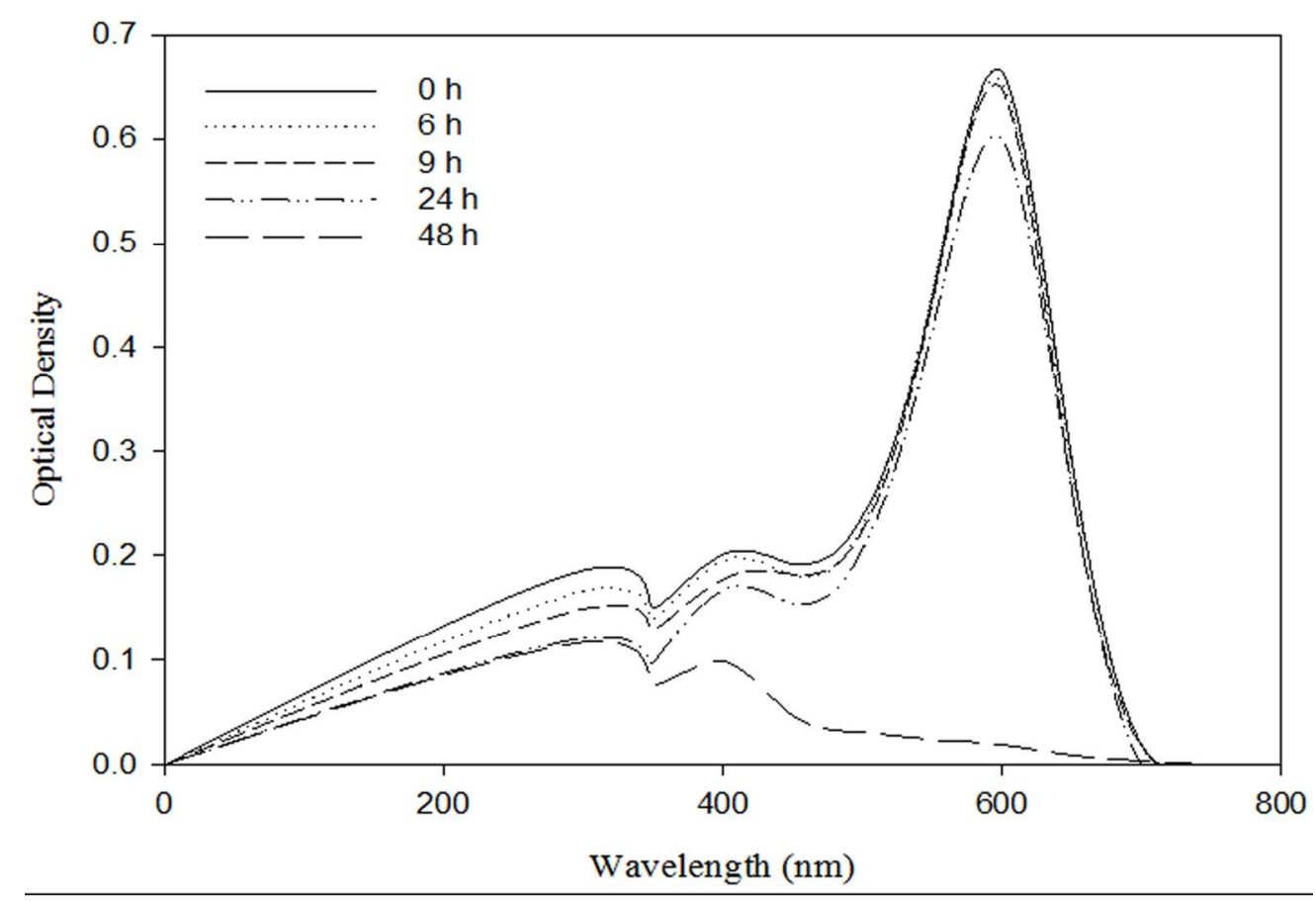

$121 \times 85 \mathrm{~mm}(300 \times 300$ DPI $)$ 


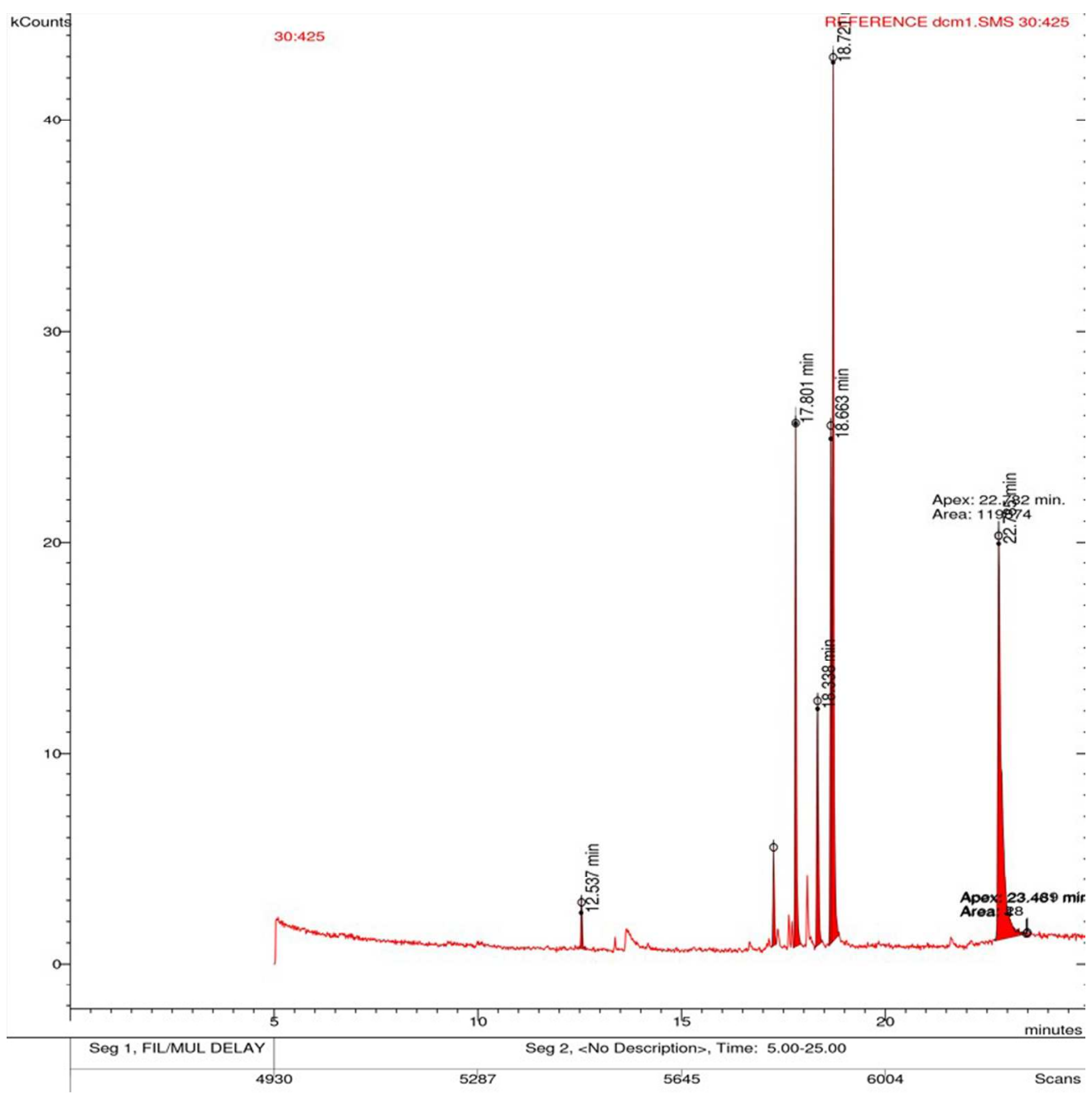

$147 \times 147 \mathrm{~mm}(300 \times 300$ DPI $)$ 
Table 1. Characteristics of Reactive Black 5 (Remazol Black B) dye used in this study.

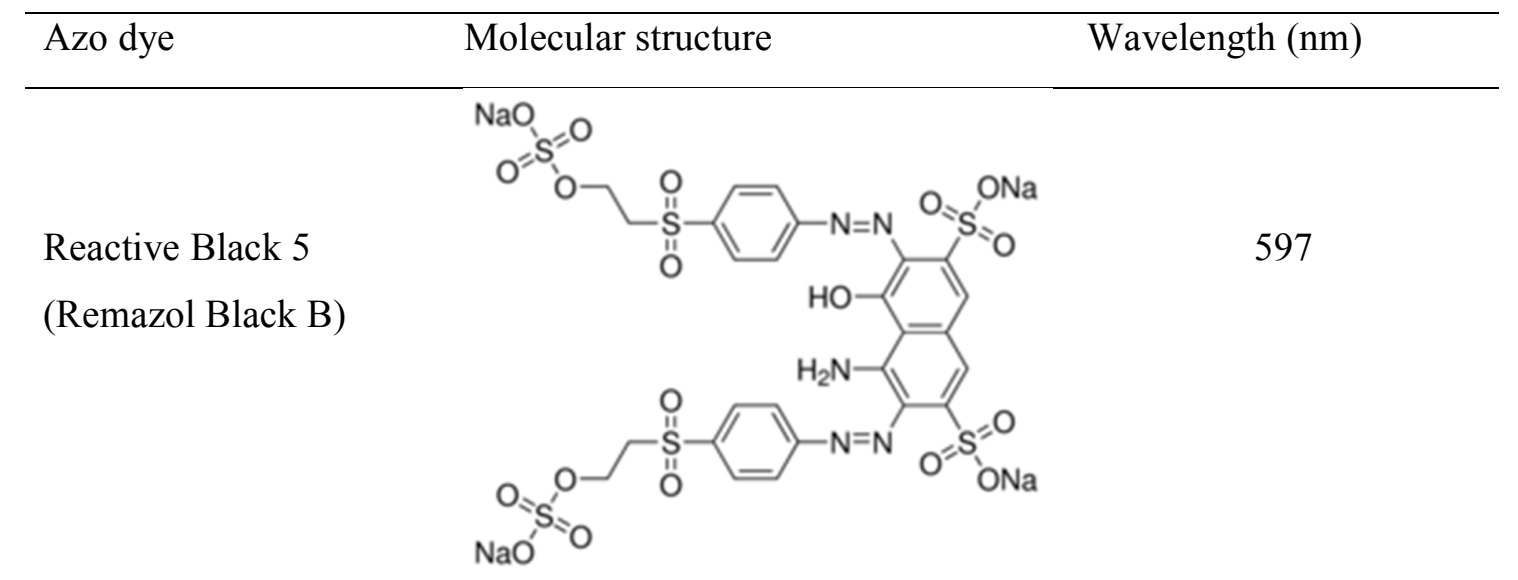

Source:http://www.sigmaaldrich.com/catalog/product/sial/306452?lang=en\&region=IN\# 
Table 2. Compounds identified in textile wastewaters using GC-MS.

\begin{tabular}{ll}
\hline Sample & Compounds identified \\
\hline Site 1 (acidic DCM fraction) & Cyclic octaatomic sulphur \\
& 1,2-Benzenedicarboxylic acid, mono(2-ethylhexyl) ester \\
& 1,2-Benzenedicarboxylic acid, diisooctyl ester \\
& Urs-9(11)-en-12-one-28-oic acid, 3-acetoxy-, methyl ester \\
& 17-Pentatriacontene \\
\hline Site 1 (basic DCM fraction) & 2,4-bis(1,1-dimthylethyl)-phenol \\
& $(1,1$ '-Biphenyl)-2-amine \\
& Azobenzene \\
& $(1,1$ '-Biphenyl)-4-amine \\
Benzidine & 1,2-Benzenedicarboxylic acid, mono(2-ethylhexyl) ester \\
& 1,2-Benzenedicarboxylic acid, diisooctyl ester \\
N-phenyl-4-(phenylazo)-benzenamine
\end{tabular}


Table 3. Determination of enzyme activity in cell-free extract.

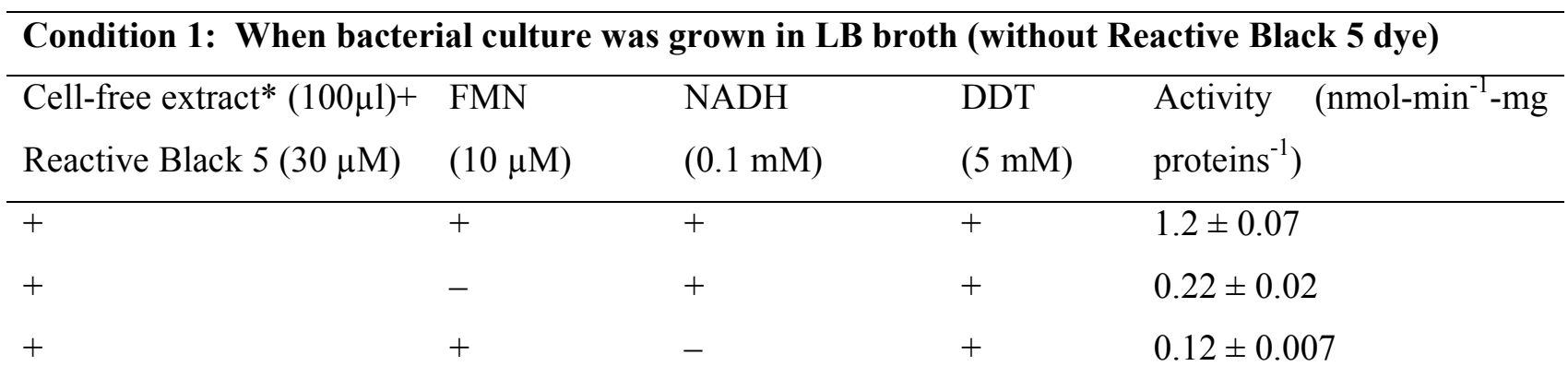

\begin{tabular}{lcccc}
\hline \multicolumn{4}{l}{ Condition 2: When bacterial culture was grown in LB broth (with Reactive Black 5 dye) } \\
\hline+ & + & + & + & $0.60 \pm 0.03$ \\
+ & - & + & + & $0.14 \pm 0.01$ \\
+ & + & - & + & 0.00 \\
+ & + & + & - & $0.38 \pm 0.02$ \\
+ & - & - & - & 0.00 \\
+ & - & - & + & 0.00 \\
+ & - & + & - & 0.00 \\
+ & + & - & - & 0.00
\end{tabular}

Condition 3: When cell-free extract was dialyzed (bacterial culture was grown in LB broth with Reactive Black 5 dye)

\begin{tabular}{lllll}
\hline+ & + & + & + & $0.38 \pm 0.025$ \\
+ & - & + & + & 0.00 \\
+ & + & - & + & 0.00 \\
+ & + & + & - & 0.00 \\
+ & - & - & - & 0.00 \\
+ & - & - & + & 0.00 \\
+ & - & + & - & 0.00 \\
+ & + & - & - & 0.00 \\
\hline
\end{tabular}

* no activity was recorded in the absence of cell free-extract.

'+' indicates that the particular substance was in the reaction mixture and '-' indicates that it was not added in the reaction mixture. 